\title{
A project-based Mine Closure Model (MCM) for sustainable asset Life Cycle Management
}

\author{
A. Fourie and A.C. Brent \\ Life Cycle Engineering, Department of Engineering and Technology Management, \\ University of Pretoria, Pretoria 0002, South Africa
}

\begin{abstract}
Responsible Life Cycle Management (LCM) of mines has received much attention in the South African legislation. However, there is currently a mis-alignment between the mining industry and the various government authorities pertaining to the issue of mine closure or end-of-life management. The main reasons for this are unclear and unformulated approaches to rehabilitation with a subsequent legacy of unsuccessful mine closures that have wrongly been issued by the government from a sustainability perspective; this has posed an excessive economical burden for the mining industry. In this paper, a Mine Closure Model (MCM) based on project management principles, including risk management and concurrent engineering, is proposed to manage the closure process and assist the governing body with the effective evaluation of closures and the issuance of certificates. Mine closure or rehabilitation objectives can be achieved whilst managing the resources (of industry) optimally and aligning the closure process to meet the end requirements of stakeholder groups.
\end{abstract}

\section{Article Outline}

1. Introduction

1.1. Historical developments and the current state of mine closures in South Africa

1.2. Objectives of this paper

2. Management approaches for the rehabilitation of mines

2.1. Project managing rehabilitation

2.2. Risk managing rehabilitation

2.3. Concurrent engineering rehabilitation

3. Current rehabilitation models

3.1. Best practice - Case A

4. Proposed project-based Mine Closure Model (MCM)

4.1. Correlating rehabilitation with project phases

4.2. Advantages of applying the MCM to Case A

5. Conclusions

References 


\section{Introduction}

Historically, mining activities have strongly dominated the South African economy, together with agricultural production. Disproportional to its geographical size, South Africa has an immense concentration of the world's mineral wealth, the most important being chrome (76\% of the world's reserves), PGMs (56\%), gold (52\%), vanadium (44\%), manganese (80\%), alumino-silicates (37\%), vermiculite (40\%) and gem diamonds [1]. Similarly, coal, which is the primary fuel produced and consumed in South Africa, is also one of the country's largest sources of foreign exchange. The national coal reserve is currently estimated to be the world's seventh largest, amounting to approximately $5 \%$ of the world reserves [2]. In the 1960s, the mining sector accounted for over $12 \%$ of the country's Growth Domestic Product (GDP). Although its importance reduced to between 5 and $6 \%$ of national GDP at the turn of the century [3], it continues to be an important sector of the national economy [4].

Currently, South African mineral exploration is at a high level, with old reserves having depleted and substitutions required [5]. If exploration leads to the construction of a successful mine, the Environmental Management Plans (EMPs) that are required by the South African legislation typically refer to some sort of Rehabilitation End Standard in a vague manner [6]. However, no details are provided in the general mine life cycle models (see Fig. 1) [7].

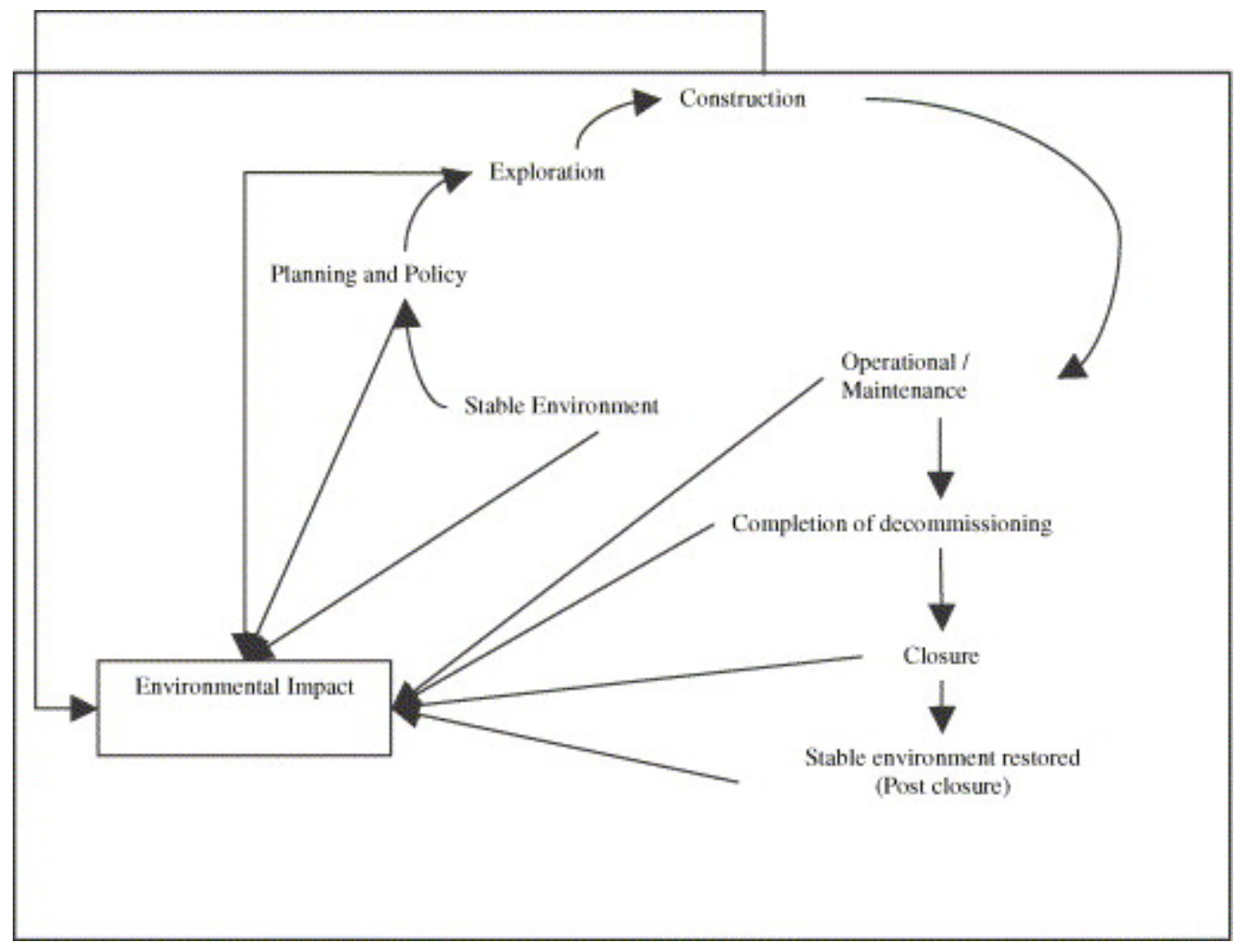

Fig. 1. A general mine life cycle model [7]. 
The mining of non-renewable resources has various known impacts on the natural environment throughout the life cycle. Table 1 indicates the general stages of mine development, and summarises the activities and environmental issues associated with each stage. In South Africa, there is growing awareness of the environmental legacy of mining activities that have been undertaken with little concern for the environment. Unfortunately, the legislation and technology in place to protect natural resources remain imperfect [5] and [8]. Changes in laws, technologies and attitudes have begun to address some of the most immediate threats posed by mining activities, but there remains many areas of mining practices and regulations that need to be addressed. Most often, the gap is caused by limited knowledge and reluctance to accept responsibility for the legacy of environmental failures [5].

Table 1.

Mining activities versus environmental issues

\begin{tabular}{|c|c|c|}
\hline \multicolumn{2}{|c|}{ Development potential activities phase } & \multirow{2}{*}{$\begin{array}{l}\text { Environmental issues (subject to } \\
\text { mitigation/prevention measures) }\end{array}$} \\
\hline Exploration & $\begin{array}{l}\text { Airborne and ground-based } \\
\text { geo-chemical, and geophysical } \\
\text { surveys, prospecting, claim } \\
\text { staking, line cutting, stripping, } \\
\text { drilling and trenching, road/trail } \\
\text { building and/or helicopter } \\
\text { transport, bulk sampling. }\end{array}$ & \\
\hline $\begin{array}{l}\text { Mining and } \\
\text { milling }\end{array}$ & $\begin{array}{l}\text { Environmental impact } \\
\text { assessment, mine design and } \\
\text { construction, stripping/storing } \\
\text { of “overburden” of soil and } \\
\text { vegetation, ore extraction, } \\
\text { crushing/grinding of ore, } \\
\text { flotation or chemical } \\
\text { concentration of ore, mine and } \\
\text { surface water treatment, storage } \\
\text { of waste rock and tailings. }\end{array}$ & $\begin{array}{l}\text { Wildlife and fisheries habitat loss, } \\
\text { changes in local water balance, } \\
\text { sedimentation, containment of toxins in } \\
\text { tailings ponds and/or leaching solutions, } \\
\text { tailings ponds or leaching pads stability } \\
\text { failure, potential acid generation from } \\
\text { waste rock and pit walls, heavy metal } \\
\text { leaching from acid mine drainage, } \\
\text { cyanide solution containment at heap } \\
\text { leach operations, wind borne dust. }\end{array}$ \\
\hline $\begin{array}{l}\text { Smelting } \\
\text { and refining }\end{array}$ & $\begin{array}{l}\text { Processing of mineral } \\
\text { concentrate by heat or electro- } \\
\text { chemical processes. }\end{array}$ & $\begin{array}{l}\text { Sulphur dioxide emissions contribute to } \\
\text { acid rain, toxic chemical (e.g. ammonia, } \\
\text { sulphuric acid) use for processing, high- } \\
\text { energy requirement. }\end{array}$ \\
\hline $\begin{array}{l}\text { Mine } \\
\text { closure }\end{array}$ & $\begin{array}{l}\text { Re-contouring of pit walls, and } \\
\text { waste dumps, covering of }\end{array}$ & $\begin{array}{l}\text { Seepage of toxic solutions into ground } \\
\text { and surface water contamination from }\end{array}$ \\
\hline
\end{tabular}




\begin{tabular}{|l|l|l|}
\hline \multicolumn{2}{|l|}{ Development potential activities phase } & $\begin{array}{l}\text { Environmental issues (subject to } \\
\text { mitigation/prevention measures) }\end{array}$ \\
\hline & $\begin{array}{l}\text { reactive tailings dumps, de- } \\
\text { commissioning of roads, } \\
\text { dismantling of buildings, re- } \\
\text { seeding/planting of disturbed } \\
\text { areas, ongoing monitoring and } \\
\text { possible water quality } \\
\text { treatment. }\end{array}$ & $\begin{array}{l}\text { acid mine drainage, wildlife and } \\
\text { fisheries habitat loss, re-vegetation } \\
\text { failure, wind borne dust, slope and } \\
\text { tailings impoundment failure. }\end{array}$ \\
\hline
\end{tabular}

The rehabilitation of mine sites should ideally be planned before any mining commences using the data provided by exploration. In particular, the data should include physical, chemical, hydrological and geo-technical properties of the ore, gangue and country rocks, and should be used to develop the Environmental Management Plan (EMP) [9]. This implies the principles of concurrent engineering. An EMP is also necessary for operational mines to ensure that the best result is achieved, and that the communities and regulatory authorities are satisfied.

Some of the factors that must be considered with mine rehabilitation are as follows [9]:

- Physical and chemical stability of mine waste dumps and open-pits.

- Maintenance of water quality.

- Safe disposal of infrastructure.

- Development of sustainable ecosystems.

- Meeting community expectations.

\subsection{Historical developments and the current state of mine closures in South Africa}

Most mines that are still in operation today in South Africa are in excess of 50 years old. When opened, the mining planning and methods did not acknowledge ecological impacts and effects to the same extent as they do at present. Legislation has also changed and the Environmental Management Programme Reports (EMPRs) that are mandatory in South Africa are lacking the management of risks, and concurrent engineering throughout the life cycle, in order to ensure that all of the commitments to stakeholders are aligned with responsibility towards the environment [10]. The EMPR is merely a list of "What" needs to be done and lacks the aspects of "How" it should be done and "Why" it is the best option [10].

Over the years, the mining industry in South Africa has experienced uncertainty as to how to manage the associated impacts of mining closures in order to leave mine sites in successfully rehabilitated states. However, mine closure certification can now be secured from the South African national Department of Minerals and Energy (DME) [6]. By issuing a closure certificate, the government relieves a mine owner of obligations that might follow as a result of pollution and negative environmental impacts. Even in South Africa, the regulating body (DME) is reluctant to accept the burden of the past failures due to the inability and ignorance of mining houses to plan and manage the 
environmental risks associated with mining actions and make sufficient financial provision for the rehabilitation. Due to these delays, closure certificates are not currently issued to mines. The responsibility of all impacts remains with the mining company, with large associated financial burdens.

The consulting industry in South Africa has responded in order to establish better ways of managing the rehabilitation process. In one example, risk-based models have been developed to prioritise rehabilitation requirements specifically applied to asbestos mines [11]. This was necessitated due to limited financial resources. In another instance, the national DME is assisted with the development of legislation and specific plans for mine closure, based on risk management [7]. Even with guidelines and requirements such as the New South Wales' governing documents on performance reports and land usage [12] and [13] and the requirements of the Minerals Act 50 of 1991 [8], there is still not a firm, established and recognised management-based model to guide the pre-closure work and post-closure evaluations over the long term.

Consultants execute a number of loosely structured phases, and the DME is not always clear as to how to evaluate the unstructured methods and reduce the risk of an unsuccessful closure. With the confusion and associated financial burdens of delays, the mining industry is starting to take two approaches:

- Focus more and more on inexpensive means of just complying with the "esthetical nuisance", rather than strategising to solve long-term effects.

- Over-run rehabilitation efforts in order to exceed the public expectation.

\subsection{Objectives of this paper}

With specific focus on mine closure, it has been hypothesised that a model can be derived from past failures and successes, which can be developed as an integrated project in terms of total mine Life Cycle Management (LCM). A case study investigation of past experiences gained by industry, consultants and authorities may therefore correlate successes to different project management principles. Subsequently, this paper aims to capture these successes in a project-based Mine Closure Model (MCM).

By using an MCM for specific phases in mine closure, the following can be achieved:

- Industry can plan closure successfully in a formal Environmental Management Plan (EMP). The entire closure process can be viewed as a project with certain probabilistic certainties, making the planning more deterministic.

- Industry can budget more accurately based on scenarios generated by the project plan, including contingency plans and impact risks.

- The DME can better understand the process followed by the mine and, in using the MCM, objectively evaluate closure proposals to later issue closure certificates based on the requirements.

- The government through the DME manages all unsuccessful closures. This places an obligation on the taxpayers for the cost. By achieving more successful closures, this 
burden to the taxpayers will be reduced. The government's reluctance to award mine closure or even refraining from being involved with mine closures might be improved. - At present, the issues surrounding environmental impacts and irreversible pollution caused by closed mines are very controversial. The MCM may improve the relationship between mine owners, government and the public at large to achieve successful closures for all Interested and Affected Parties (I\&Aps).

The goal of the developed project-based MCM is therefore to obtain certification in a responsible manner so as to successfully achieve closure of mines in the context of the new environmental legislation in South Africa.

\section{Management approaches for the rehabilitation of mines}

In order to derive the Mine Closure Model, three management approaches for the rehabilitation of mines are considered. They are as follows: Project Management, Risk Management, and Concurrent Engineering. Each is examined in turn.

\subsection{Project managing rehabilitation}

Projects are, by definition, "a proposal of something to be done; plan; an organised undertaking; special unit of work, research etc.; an extensive public undertaking, as in conservation, construction, etc.” [14]. A project is a unique requirement that involves: - A single definable purpose;

- A temporary activity with a start and end; and

- A process of working to achieve the objectives.

With respect to rehabilitation, "the main objective of a restoration and rehabilitation programme for a surface mine is to create a self-sustaining land surface which can in the long term be put to some productive use" [9]. Thereby, rehabilitation can be managed in a similar manner to normal projects in industry. The associated phases within projects are the pre-feasibility, conceptual phase and the scope of work, followed by execution and post-project evaluation [9]. The required work breakdown structures are generated with detailed time scheduling based on these phases. Stakeholder involvement and continuous monitoring of environmental impacts are imperative to achieve success.

\subsection{Risk managing rehabilitation}

Project risk management "is about people making decisions to try to optimise the outcome, being proactive in evaluating risk and the possible responses, using this information to best effect, demonstrating the need for changes in project plans, taking the necessary actions and monitoring the effects" [15]. This technique can be used in the rehabilitation of mines, whereby the environmental criteria of actions relative to the safety of the surrounding environment and communities are evaluated. The technique verifies and prioritises actions on, and costs of, particular areas [14]. The principle is 
examined later in the paper through a case study where it was successfully used with the rehabilitation of a South African opencast coalmine.

Within the normal processing of mining options, decisions are often based upon production and economical pressures in the short term. These actions have consequences on the original Environmental Management Programme Report (EMPR) that was approved by authorities, and should be addressed differently in the Rehabilitation Plan. It can be seen as a Project Contingency Plan that must be initiated. However, these plans will have long-term risks and should be evaluated formally and documented. The Project Risk Management approaches that are available make provision for these decisions to be taken responsibly [15].

\subsection{Concurrent engineering rehabilitation}

Concurrent engineering includes all aspects of a defined process. For example, in a product industry, it will include sales, marketing, purchasing, finance, quality and design from the conceptual stage to de-commissioning, which is the typical "cradle to grave" design approach [14].

With regard to the Mine Life Cycle (MLC) phases, concurrent engineering should be applied from the initial planning of the mine to the eventual post-closure phase as an input into the Rehabilitation Plan. This helps to ensure alignment of all operational activities to the rehabilitation process, thus ensuring minimum impacts on the environment throughout the MLC. Should operational decisions be made to change mining methods or basic processes, this information should be reviewed against the Rehabilitation Plan to consider the long-term effects, and not only the short-term effects, as is often the case due to immediate economic pressures. This can be applied to each phase of the MLC in order to ensure the whole focus remains on leaving a mined area in a stable and socially acceptable state, without having an uncontrolled environmental impact during and after the rehabilitation phase.

The way in which exploration is executed should also be incorporated into the final Rehabilitation Plan in order to evaluate all options and establish exploration practices with minimal environmental and financial burdens.

\section{Current rehabilitation models}

A number of historic case studies that were investigated revealed that mine rehabilitation is not undertaken using a holistic project management approach [10]. At present, there is a limited approach towards a holistic process to manage rehabilitation from the conceptual phase, to physical stability and ecological sustainability [5]. The focus of the authorities to only use the EMPR (desired standard of end product) is misleading. The initiatives of the consulting industry are applied to put Rehabilitation Plans into place. Even these detailed Rehabilitation Plans are insufficient to adapt contingency plans in order to ensure that the objectives of the EMPR are met. However, the current South African industry best practices have the advantage of high ecological quality, on time and 
within the required rehabilitation budget. A rehabilitation model is introduced, which has been derived from best practice and successes achieved with certain approaches towards the rehabilitation of South African mines [7].

\subsection{Best practice - Case A}

The mine that is investigated is an opencast coalmine, situated in the savannah grassland region of the Mpumalanga Province of South Africa. The mine occupies $20 \mathrm{~km}^{2}$ of land in a quality grazing agricultural district with a main river of the region flowing past the opencast area.

The coalmine produced approximately seven million tonnes of low quality coal annually, used in the country's petrochemical industry to produce liquid fuel. The opencast operation began production in 1989 and the designed life of the mine was 20 years, although the mining activities influenced the ground water levels and surface drainage in a major way. Due to geological difficulties and associated extreme cost pressures, the mine was de-commissioned in 2003. The mining equipment was still available for 18 months after de-commissioning and the rehabilitation would have been undertaken during this period. However, very little time was available to plan the rehabilitation, and when it did commence, it was discovered that the original EMPR made provision for the specification of only one slope angle of spoils and the water drainage option was found to be unpractical and uneconomical (i.e. internal evaporation of storm water calculated to be a high cost in the long term). The authorities did not supply any guidelines, and the operating company opted to investigate additional rehabilitation processes and options with assistance from a reputable consultant. Other mine rehabilitation sites were visited, processes investigated and shortcomings reviewed. It was subsequently decided to modify the EMPR, which is not typically the procedure.

Different technical options and designs were then evaluated, and the optimal long-term solution was identified. It was found, based on Risk Management principles, that a third option using free drainage of storm water was more acceptable for rehabilitation. This contradicted the original EMPR, but nevertheless comprised a lesser risk and a higher probability for a sustainable environment after rehabilitation. The consultant designed a detailed Rehabilitation Plan that was required for the approval of the modified EMPR. A prototype rehabilitation area was completed and presented to the authorities to illustrate the end specification that complied with the modified EMPR. The interview held with the consultant involved in the rehabilitation of Case A and a similar mine rehabilitated previously revealed that the EMPR was used as a guide for the Required End Standard [8]. After appropriate risk evaluation and verification of assumptions, the new deviated and improved EMPR was approved, and rehabilitation continued against this required specification. A new approved fund was established and justification presented to the responsible decision-makers. The present value for the complete project is approximately R 184078880.00 (approximately US\$ 30 million), and if flaws are detected at a later stage in rehabilitation, it cannot be rectified easily, and would result in a failure to achieve closure [5]. Fig. 2 illustrates the project management philosophy used in the rehabilitation process of Case A [7]. 


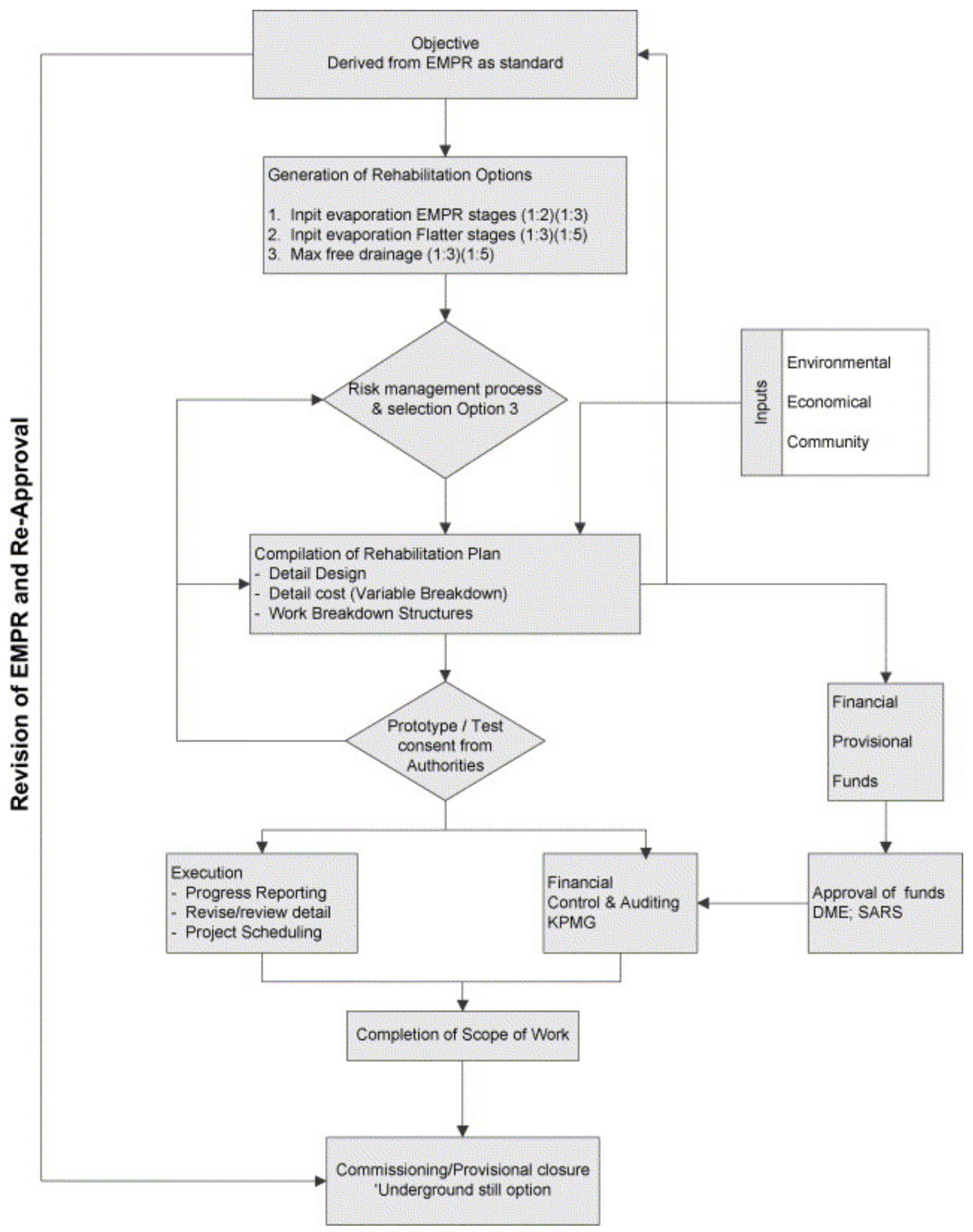

Fig. 2. Case A - rehabilitation process [7]. 
Even in the structured holistic manner of the model that has been used (see Fig. 2), some important integration, feedback systems and concurrent engineering are not addressed. Thus, the entire MLC cannot be considered when compiling the original EMPR. For Case A, this would have resulted in the provision for option three earlier in the Mine Life Cycle Management (MLCM) process. However, the model still remained flexible and structured. Successful results from the management processes are as follows:

- Financial control resulted in rehabilitation within budget. This was made possible from detailed work breakdown structures that were a result of the detailed Rehabilitation Plan. Variable cost items were included in a structured plan, against which, progress reports were drawn and audited.

- With the interactive approach, endorsement was received from the relevant authorities. A smaller section of the mine was rehabilitated and proposed as a prototype from which authorities could confirm the standards in the EMPR. Although the authorities do not approve anything other than the EMPR, the fact that a structured Rehabilitation Plan was verified against the actual results and cross-referenced with the expected standards specified in the EMPR made the process more visualised.

- The Project Progress Report was plotted against the budget (Earned Value Analysis) and audited by reputable independent auditors on a regular basis. This resulted in documents that can be used as future reference for the costs involved in the rehabilitation. A structured approach of this nature also provides the advantage of fine-tuning planning through a feedback loop. This results in accurate schedules and financial commitments against achieving the scope of work accurately. It was indicated by the Project Manager of the rehabilitation of Case A that success was achieved largely because of a strict adherence to the detail of the Rehabilitation Plan.

- The time constraint was met through Project Scheduling used by the dedicated Project Manager. This saved considerable cost, as no additional equipment was hired to complete the rehabilitation and no rework of the slopes was needed.

- Detailed project documentation was compiled and may be used to substantiate decisions if required in the future.

The case resulted in the successful partial closure of the mine; due to the ongoing underground operations, closure was not applied for based on an economical advantage. Fig. 3 illustrates the results that were achieved [7]. 


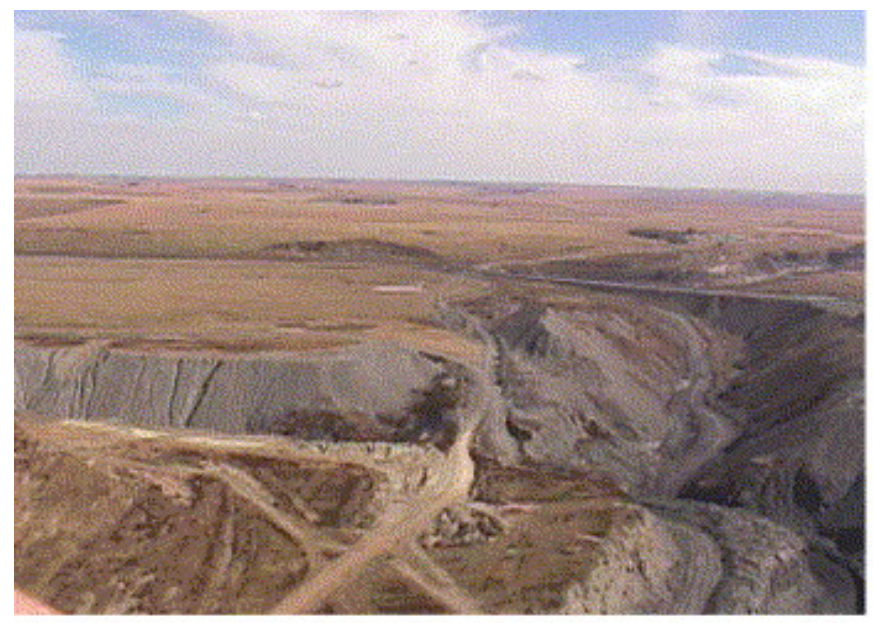

Before Rehabilitation

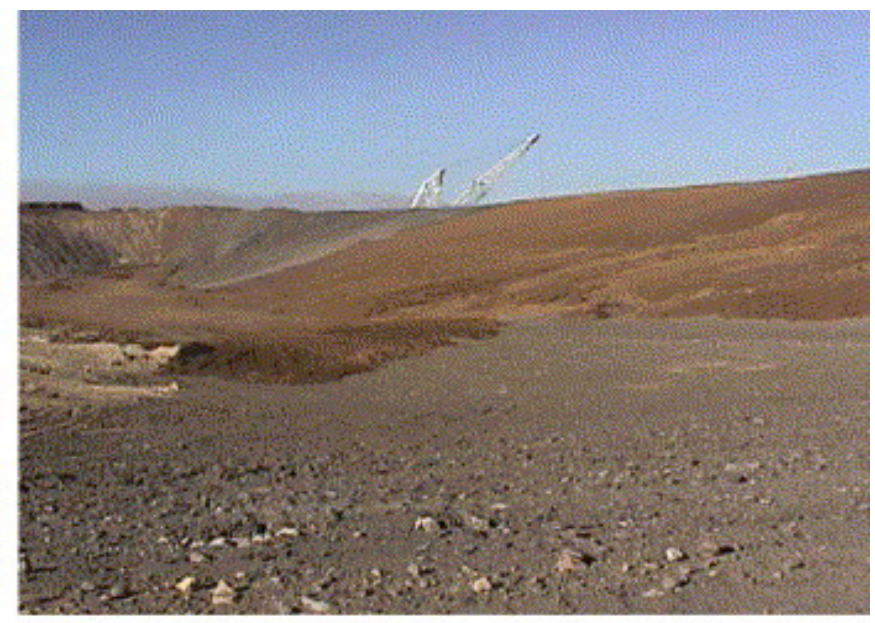

After Rehabilitation

(Vegetation still required)

Fig. 3. Case A - rehabilitation photographs [7].

\section{Proposed project-based Mine Closure Model (MCM)}

The project management model, as described in the Project Management Body of Knowledge (PMBOK) [16], has been executed within numerous other industries' unstructured, poorly defined and uncertain projects with measured success [15]. The PMBOK model can thus be seen as a generic but rugged model as a structured approach to achieving a desired outcome. It is a collection of processes and knowledge areas generally accepted as best practice within the project management discipline. As an internationally accepted standard [17], it provides the fundamentals of project management, irrespective of the type of project. The PMBOK model recognises five basic processes or concepts that are applicable to projects, programs and operations:

- Initiating;

- Planning;

- Executing;

- Controlling; and

- Closing.

The PMBOK project management process thereby presents formal steps and phases that direct resources towards an end required state. This implies that there is no iteration procedure in order to ensure a better end result and that the original design shall be achieved with the first attempt. This is particularly required with rehabilitation. The required end state after the completion of mining activities is a stable environment that can be used for an unlimited period for recreational, productive or natural purposes. A company needs to embark on the rehabilitation phase with the aim to succeed and to optimally allocate financial resources with no long-term obligations. In the rehabilitation process, a limited financial fund is approved before rehabilitation commences. It is not 
feasible to keep extending commitments until the end result is finally achieved after a number of attempts. The PMBOK process particularly leans itself towards this requirement in terms of establishing a known direction and detailed plan with work breakdown structures and measurement techniques to proactively activate contingency plans and mitigate risks before failure occurs.

\subsection{Correlating rehabilitation with project phases}

The project-based Mine Closure Model (MCM) is therefore based on the project management phases as per the PMBOK model [16]. Table 2 correlates the phases of the PMBOK model with the requirements of rehabilitation that have been documented [9]. Also, a process is required by the US Rehabilitation Legislation, which indicates the importance of cooperation and following a systematic approach [18]. Thereby, each Rehabilitation Plan shall supply, although not be limited to, the information shown in Table 2.

Table 2.

PMBOK project phases [16] versus rehabilitation phases [9]

\begin{tabular}{|c|c|c|c|}
\hline $\begin{array}{l}\text { Project phases } \\
\text { (PMBOK) }\end{array}$ & $\begin{array}{l}\text { Related mine } \\
\text { rehabilitation }\end{array}$ & & \\
\hline \multicolumn{4}{|l|}{ Feasibility } \\
\hline $\begin{array}{l}\text { Project } \\
\text { formulation }\end{array}$ & $\begin{array}{l}\text { Legislation, EMP, } \\
\text { customer } \\
\text { requirements }\end{array}$ & EMPR & $\begin{array}{l}\text { The steps to be taken to comply } \\
\text { with applicable air and water } \\
\text { quality laws and regulations and } \\
\text { any applicable health and safety } \\
\text { standards }\end{array}$ \\
\hline $\begin{array}{l}\text { Feasibility } \\
\text { studies }\end{array}$ & & Pre-mining site & $\begin{array}{l}\text { The identification of the lands } \\
\text { subject to surface coal mining } \\
\text { operations over the estimated } \\
\text { life of those operations and the } \\
\text { size, sequence, and timing of the } \\
\text { sub-areas for which it is } \\
\text { anticipated }\end{array}$ \\
\hline $\begin{array}{l}\text { Strategy design } \\
\text { and approval }\end{array}$ & $\begin{array}{l}\text { Concepts of } \\
\text { rehabilitation } \\
\text { (backfill, type of } \\
\text { vegetation } \\
\text { strategy, etc.) }\end{array}$ & $\begin{array}{l}\text { Characteristics } \\
\text { - Base line } \\
\text { - Climate } \\
\text { - Topography } \\
\text { - Soils }\end{array}$ & $\begin{array}{l}\text { The condition of the land to be } \\
\text { covered by the permit prior to } \\
\text { any mining including the } \\
\text { capability of the land prior to } \\
\text { any mining to support a variety }\end{array}$ \\
\hline
\end{tabular}




\begin{tabular}{|c|c|c|c|}
\hline \multirow[t]{2}{*}{$\begin{array}{l}\text { Project phases } \\
\text { (PMBOK) }\end{array}$} & \multirow[t]{2}{*}{$\begin{array}{l}\text { Related mine } \\
\text { rehabilitation }\end{array}$} & \multirow[b]{2}{*}{ - Vegetation } & \multirow[b]{2}{*}{$\begin{array}{l}\text { of uses giving consideration to } \\
\text { soil and foundation } \\
\text { characteristics, topography, and } \\
\text { vegetative cover, and, if } \\
\text { applicable, a soil survey }\end{array}$} \\
\hline & & & \\
\hline & & & $\begin{array}{l}\text { The consideration which has } \\
\text { been given to developing the } \\
\text { reclamation plan in a manner } \\
\text { consistent with local physical } \\
\text { environmental, and } \\
\text { climatologically conditions }\end{array}$ \\
\hline & & & $\begin{array}{l}\text { The results of test boring which } \\
\text { the applicant has made at the } \\
\text { area to be covered by the permit, } \\
\text { or other equivalent information } \\
\text { and data in a form satisfactory to } \\
\text { the regulatory authority, } \\
\text { including the location of } \\
\text { subsurface water, and an } \\
\text { analysis of the chemical } \\
\text { properties including acid } \\
\text { forming properties of the } \\
\text { mineral and overburden: } \\
\text { Provided, that information } \\
\text { which pertains only to the } \\
\text { analysis of the chemical and } \\
\text { physical properties of the coal } \\
\text { (excepting information } \\
\text { regarding such mineral or } \\
\text { elemental contents which is } \\
\text { potentially toxic in the } \\
\text { environment) shall be kept } \\
\text { confidential and not made a } \\
\text { matter of public record }\end{array}$ \\
\hline \multicolumn{4}{|c|}{ Planning and design } \\
\hline Base design & $\begin{array}{l}\text { Rehabilitative } \\
\text { plan }\end{array}$ & $\begin{array}{l}\text { Restoration } \\
\text { plan }\end{array}$ & $\begin{array}{l}\text { The use which is proposed to be } \\
\text { made of the land following } \\
\text { rehabilitation, including a }\end{array}$ \\
\hline
\end{tabular}




\begin{tabular}{|c|c|c|c|}
\hline $\begin{array}{l}\text { Project phases } \\
\text { (PMBOK) }\end{array}$ & $\begin{array}{l}\text { Related mine } \\
\text { rehabilitation }\end{array}$ & & \\
\hline & & & $\begin{array}{l}\text { discussion of the utility and } \\
\text { capacity of the reclaimed land to } \\
\text { support a variety of alternative } \\
\text { uses and the relationship of such } \\
\text { use to existing land use policies } \\
\text { and plans }\end{array}$ \\
\hline $\begin{array}{l}\text { Cost and } \\
\text { schedule }\end{array}$ & $\begin{array}{l}\text { Tenders and } \\
\text { costing }\end{array}$ & $\begin{array}{l}\text { Restoration } \\
\text { cost } \\
\text { - Post mining } \\
\text { land use } \\
\text { - Soil and soil } \\
\text { handling } \\
\text { - AMD water } \\
\text { handling } \\
\text { - Erosion } \\
\text { - Landscape } \\
\text { design and re- } \\
\text { vegetation }\end{array}$ & $\begin{array}{l}\text { A detailed description of how } \\
\text { the proposed post-mining land } \\
\text { use is to be achieved and the } \\
\text { necessary support activities } \\
\text { which may be needed to achieve } \\
\text { the proposed land use }\end{array}$ \\
\hline $\begin{array}{l}\text { Contract terms } \\
\text { and conditions }\end{array}$ & $\begin{array}{l}\text { Awarding } \\
\text { rehabilitation } \\
\text { contracts }\end{array}$ & & $\begin{array}{l}\text { The consideration which has } \\
\text { been given to making the } \\
\text { surface mining and reclamation } \\
\text { operations consistent with } \\
\text { surface owner plans, and } \\
\text { applicable State and local land } \\
\text { use plans and programs }\end{array}$ \\
\hline Detail planning & $\begin{array}{l}\text { Vegetation, water } \\
\text { seepage design }\end{array}$ & & $\begin{array}{l}\text { The engineering techniques } \\
\text { proposed to be used in mining } \\
\text { and reclamation and a } \\
\text { description of the major } \\
\text { equipment; a plan for the control } \\
\text { of surface water drainage and of } \\
\text { water accumulation; a plan, } \\
\text { where appropriate, for } \\
\text { backfilling, soil stabilization and } \\
\text { compacting, grading, and }\end{array}$ \\
\hline
\end{tabular}




\begin{tabular}{|c|c|c|c|}
\hline \multirow[t]{2}{*}{$\begin{array}{l}\text { Project phases } \\
\text { (PMBOK) }\end{array}$} & \multirow[t]{2}{*}{$\begin{array}{l}\text { Related mine } \\
\text { rehabilitation }\end{array}$} & & \multirow[b]{2}{*}{$\begin{array}{l}\text { appropriate re-vegetation; a plan } \\
\text { for soil reconstruction, } \\
\text { replacement, and stabilization }\end{array}$} \\
\hline & & & \\
\hline \multicolumn{4}{|c|}{ Production/Operation } \\
\hline Manufacturing & $\begin{array}{l}\text { Physical } \\
\text { earthmoving, } \\
\text { form work and } \\
\text { planting of } \\
\text { vegetation }\end{array}$ & & \\
\hline Delivery & $\begin{array}{l}\text { Commissioning of } \\
\text { part completion }\end{array}$ & & \\
\hline Civil works & See above & & \\
\hline Installation & See above & & \\
\hline Testing & $\begin{array}{l}\text { Inspection by } \\
\text { Government }\end{array}$ & Plan & $\begin{array}{l}\text { A detailed description of the } \\
\text { measures to be taken during the } \\
\text { mining and reclamation process } \\
\text { to assure the protection of: } \\
\text { - The quality of surface and } \\
\text { ground water systems, both on- } \\
\text { and off-site, from adverse } \\
\text { effects of the mining and } \\
\text { reclamation process } \\
\text { - The rights of present users to } \\
\text { such water } \\
\text { - The quantity of surface and } \\
\text { ground water systems, both on- } \\
\text { and off-site, from adverse } \\
\text { effects of the mining and } \\
\text { reclamation process or to } \\
\text { provide alternative sources of } \\
\text { water where such protection of }\end{array}$ \\
\hline
\end{tabular}




\begin{tabular}{|l|l|l|l|}
\hline $\begin{array}{l}\text { Project phases } \\
\text { (PMBOK) }\end{array}$ & $\begin{array}{l}\text { Related mine } \\
\text { rehabilitation }\end{array}$ & \multicolumn{2}{|l|}{} \\
\hline & & & \\
\hline $\begin{array}{l}\text { Turnover and } \\
\text { start up }\end{array}$ & quantity cannot be assured \\
\hline Final testing & $\begin{array}{l}\text { Closure } \\
\text { certification }\end{array}$ & & \\
\hline Maintenance & $\begin{array}{l}\text { Sustainable } \\
\text { remote monitoring } \\
\text { of environment }\end{array}$ & & \\
\hline
\end{tabular}

Using the PMBOK model as a basis and incorporating the advantages that have been achieved through the model applied for Case A, a Mine Closure Model (MCM) is derived to achieve closure through a controlled project management approach. Fig. 4 illustrates the derived MCM. 


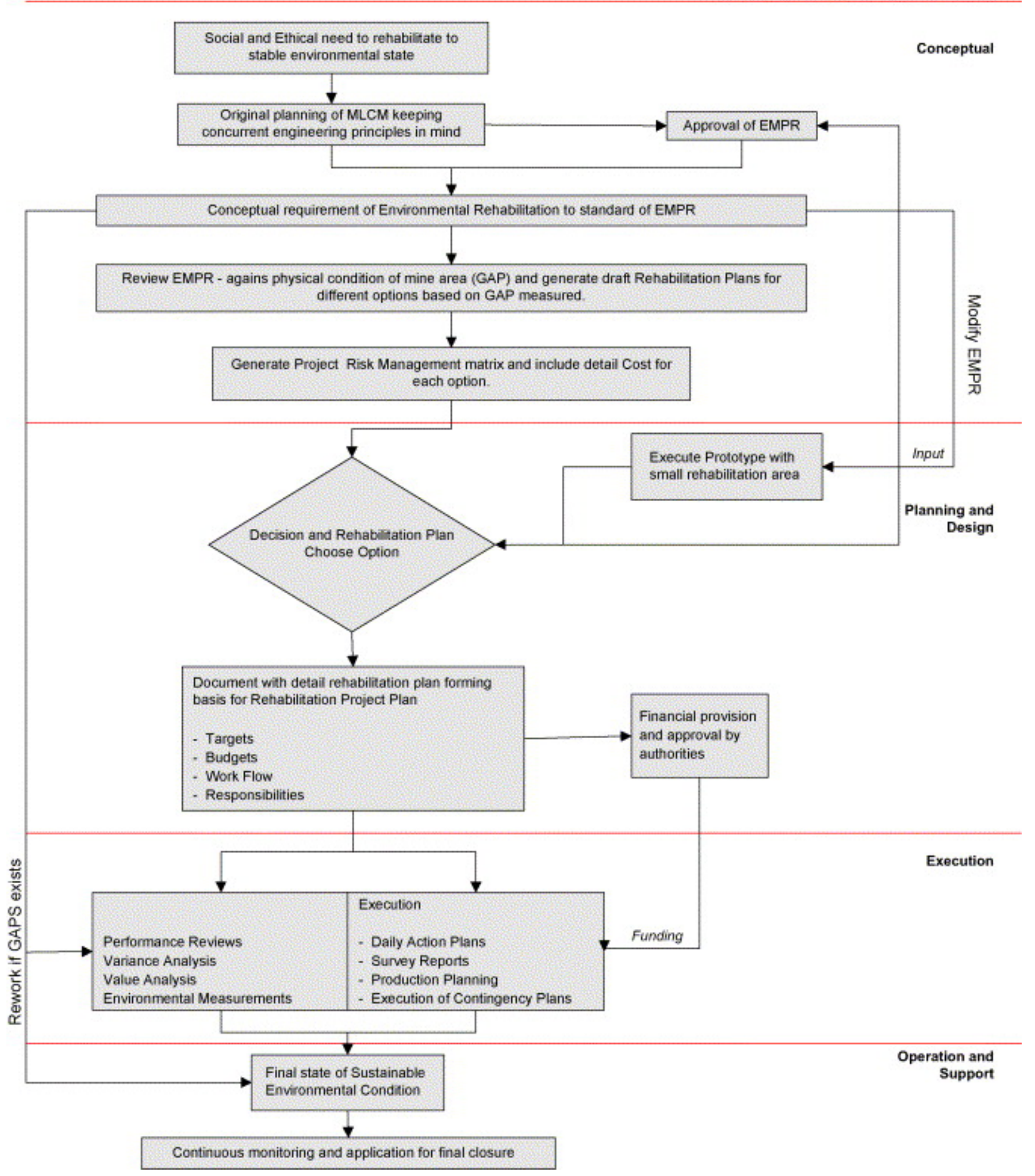

Fig. 4. Derived Mine Closure Model (MCM). 
The philosophy is to be able to apply this model in a flexible manner, but that some guidelines are provided to integrate the different interactive focus points that were previously used to drive rehabilitation actions involved with mining. Instead of the conventional project (e.g. to control contaminated wastewater), a holistic focus is given to drive balanced actions with contained cost towards successful mine closure.

The model splits specific rehabilitation actions related to the proven project management phases indicating the timing and importance of completion within the process. The EMPR is merely a benchmark standard, against which, the results of the Rehabilitation Plan are measured. The timing of the financial funding only follows after a detailed Rehabilitation Plan is composed ensuring that the funds are in line with the detailed design. To improve the accuracy of the theoretical plan and the standard required by the approved EMPR, a prototyping or testing phase is built into the MCM. It is suggested that no uncalculated changes are made to the Rehabilitation Plan when executing the rehabilitation.

In older mines where the EMPR is not applicable, a baseline should be determined that indicates the gap (Scope of Work) between the required state and current state of the environment. Thereafter, the management process follows the guidelines of the proposed MCM.

The model makes provision for continual monitoring of water flow, and quality and stability of the vegetation and rehabilitated slopes. This not only confirms assumptions made, but can be used to reiterate efforts or even to prove success towards achieving the final mine closure.

\subsection{Advantages of applying the MCM to Case A}

The allocated rehabilitation fund for Case A is approximately US\$ 30 million, and with $90 \%$ of rehabilitation completed (as at the beginning of 2004), there are no deviations from the original cost estimate and project schedule. The advantage of the PMBOK method of project management with the associated financial controls (e.g. the Cash Flow Curves and Earned Value Analysis used in Case A) was that it guided the Project Manager to stay exactly in line with the project plan. A similar rehabilitation project that used the EMPR as a required end state, but which did not follow the formal management model, resulted in the overspending of funds in the order of 10-30\% [10]. Without the detailed work breakdown structures, the mining company is at risk of financial burdens due to not achieving the required end result with consequent environmental liabilities after completion.

The proposed MCM makes provision for proactive risk management and concurrent engineering processes that were not used in Case A. In Case A the suggested PMBOK process was followed in the alignment of the Rehabilitation Plan. However, some improvements and flexibility can be incorporated in the management process if the consequences that mining actions have on the rehabilitation process are better understood at the time of execution. Thereby, actions can be taken beforehand in order to achieve the rehabilitation specifications and prevent over-expenditure or failure to meet the originally 
scheduled milestones. This makes the rehabilitation process easier to audit at any stage and thereby reduces the risks of liabilities identified by stakeholders. Authorities can confidently base approval on the formalised process, audit the application of resources on the different rehabilitation phases, and issue Mine Closure certificates.

\section{Conclusions}

This paper introduces some major challenges with mine closure in South Africa, and examines the mis-alignment of (South African) authorities and mining companies regarding rehabilitation as a phase in Mine Life Cycle Management (MLCM). This misalignment results from the existing lack of structure, which is attributable to not following a formalised project management approach to mine rehabilitation. By structuring mine rehabilitation into project management phases (i.e. objectives, feasibility, detail design, testing, execution, control, and completion), and including additional working tools such as risk management processes to prioritise options, together with concurrent engineering principles to address each aspect of the Mine Life Cycle (MLC), the impacts and unexpected conditions of the MLC can be integrated with environmental requirements. Experiences in the South African mining industry indicate that some gaps do exist, and that best practise leans towards an integrated project management approach (Fig. 2).

Based on these industry experiences, a Mine Closure Model (MCM) was derived (Fig. 4). Past closure failures are shown to be avoidable, as all aspects are continuously integrated and managed to a desired end state - namely the EMPR. Industry resources and financial funds can be motivated to improve the accuracy of evaluated risks, and complex negative impacts can be managed in a Project Risk Management system that generates contingency plans in alignment with environmental objectives. Deviations can be structured, as well as the costs contained before negative impacts occur due to wrongful acts or shortage of funds.

The suggested MCM aligns the focus of South African authorities and mining companies towards achieving the required environmental state specified in the EMPR at the initial start of the mining activities (i.e. extraction). At present, the South African authorities emphasise that the management of mining companies should accept the long-term liabilities of their actions. On the one hand, companies overreact by investing ineffective financial resources to overcompensate. On the other hand, other side mining companies believe that a mine closure will not be achieved, and thus attempt to bypass liabilities or only make provision for liability claims but neglecting the environment in the longer term.

By using the MCM as a formal and transparent process, the South African authorities can audit actions taken and provisionally state their acceptance of the suggested process towards mine closure. It is further possible for a mine company to accurately allocate financial funds and manage rehabilitation with an aim of achieving mine closure in a responsible manner, knowing that the long-term environmental burdens were made part of each phase in the MLC. 


\section{References}

[1] South African Government Communication and Information System (GCIS), Minerals and mining. Pocket guide to South Africa 2003<http://0www.gcis.gov.za.innopac.up.ac.za:80/docs/publications/pocketguide.htm> [accessed on 29 April 2004].

[2] United States Energy Information Administration (EIA), South Africa. Country analysis briefs $<$ http://www.eia.doe.gov/emeu/cabs/safrica.html $>$ [accessed on 29 April 2004].

[3] Statistics South Africa. Gross Domestic Product - Fourth quarter 2001. Statistical release P0441, Pretoria, South Africa; 2002.

[4] Economist Intelligence Unit, South Africa - economic structure. Country briefings<http://0-www.economist.com.innopac.up.ac.za:80/countries/SouthAfrica/> [accessed on 29 April 2004].

[5] J. Scott, State, industry in mine closure stand-off, Mining Weekly (January 24-30, 2003).

[6] South African Department of Minerals and Energy (DME), Mine rehabilitation Environmental policies - Mine Closure<http://0-www.dme.gov.za.innopac.up.ac.za:80> [accessed on 29 April 2004].

[7] C. Van Renssen, Syferfontein mine. Rehabilitation plan, Van Renssen \& Fertuih (Pty) Ltd, Pretoria, South Africa (2003).

[8] South African Department of Minerals and Energy (DME). Minerals Act. Act no. 50 of 1991, (Pros. 123 dd. 20.12.1991) as amended by Act 103/1993 w.e.f. 1/9/93 Proc. 75/1993 except for section 18 which substitutes s.45(4) w.e.f. 1/1/92, Mine Health and Safety Act 29/1996, Pretoria, South Africa; 1992.

[9] F.G. Taylor, Pollution control and minesite rehabilitation in surface coal mining. SCIRO environmental projects office, Osmond, Australia<http://apecegcfe.fossil.energy.gov/TILF_VN2000/taylor\%20paper.PDF> [accessed on 30 March 2004].

[10] A. Fourie, Personal interview with Van Renssen C., Van Renssen \& Fertuih (Pty) Ltd (2003).

[11] In: J. Booysen, Editor, The Asbestos edition. EKO TALK Newsletter of the Institute for Ecological Rehabilitation, University of Potchefstroom, Potchefstroom, South Africa (2002).

[12] McCarthy PL. Rehabilitation of Old Mines. Australian Mining Consultants (Pty)

Ltd, Melbourne, Australia, <http://www.amcconsultants.com.au/amcreflib.htm>

[accessed on 30 March 2004].

[13] Natural Resource Management (NRM), Mount Morgan Rehabilitation

Project $<$ http://0-

www.nrm.qld.gov.au.innopac.up.ac.za:80/mines/environment/mt_morgan/> [accessed on 30 March 2004].

[14] M.J. Nicolas, Project management for business and technology, Prentice Hall, Inc., Upper Saddle River, New Jersey (2001).

[15] C. Chapman and S. Ward, Project risk management, processes, techniques and insights, John Wiley \& Sons, Chichester, West Sussex (1997). 
[16] R.W. Duncan, A guide to the project management body of knowledge (PMBOK ${ }^{\circledR}$ Guide), Project Manage Institute (PMI), USA (2000).

[17] Institute of Electrical and Electronics Engineers (IEEE), IEEE guide (C IEEE) adoption of PMI Standard - a guide to the project management body of knowledge (C) PMI) IEEE Standards online $<$ http://0-

standards.ieee.org.innopac.up.ac.za:80/catalog/olis/se.html> [accessed on 30 April 2004]. [18] The Office of Surface Mining (OSM), Postmining rehabilitation of sedimentation ponds, diversions, impoundments, and treatment facilities. 30 CFR Subchapter K Permanent Program Performance Standards, Sec. 816.56<http://www.osmre.gov/regindex.htm> [accessed on 30 March 2004].

Corresponding author. Tel.: +27 12420 3929; fax: +27 123625307. 